\title{
President Signs 'National Veterinary Medical Service Act' and 'Captive Wildlife Safety Act'
}

\section{Agriculture Secretary to Repay Student Loans of Veterinarians in Shortage Areas}

On 6 December, President Bush signed HR 1367, the 'National Veterinary Medical Service Act'. The Act authorizes the Secretary of Agriculture "to conduct a loan repayment program regarding the provision of veterinary services in shortage situations, and for other purposes.". The Act establishes a program to pay the principal and interest of qualifying educational loans of veterinarians who provide veterinary services in 'veterinarian shortage situations', or provide service to the federal government in emergency situations. The Secretary of Agriculture is to develop regulations for the amounts and repayment schedules.

According to the Act, the Secretary may consider the following to determine veterinarian shortage situations:

"Urban or rural areas that the Secretary determines have a shortage of veterinarians.

"Areas of veterinary practice that the Secretary determines have a shortage of veterinarians, such as public health, epidemiology, and food safety.

"Areas of veterinary need in the Federal Government.

"(4) Other factors that the Secretary considers to be relevant ${ }^{1}$."

Qualifying loans include those made to cover tuition, books and laboratory expenses, and living expenses for individuals receiving a DVM or equivalent degree from an accredited college of veterinary medicine. Veterinarians will receive salaries commensurate with their duties, travel and appropriate per diem reimbursements, and will not be required to serve more than 60 working days for each year of service.

\section{Regulation Update}

New ASM Publications Available

Cumitech 40: Packing and Shipping of Diagnostic Specimens and Infectious Substances In December 2003, the American Society for Microbiology (ASM) announced the release of Cumitech 40: Packing and Shipping of Diagnostic Specimens and Infectious Substances-a 16-page booklet on rules and regulations governing the shipment of biological and infectious substances ${ }^{3}$. The latest in the ASM Press series of Cumulative Techniques and Procedures in Clinical Microbiology, this publication provides a brief, authoritative, and practical guide that summarizes the recent regulations, and is designed to help individuals working with pathogens comply with national and international transport regulations and provides guidelines for shipping dangerous pathogens and toxins by land and by air.

Natural Pathogens of Laboratory Animals: Their Effects on Research Another ASM Press book of interest to scientists, veterinarians, and staff who work with laboratory animals is David Baker's Natural Pathogens of Laboratory Animals: Their Effects on Research, published in July 2003 (ref. 4). It describes the most common natural pathogens, many of which cause subclinical disease-their agents, epidemiology, clinical signs, pathology, potential for interference with research or alterations of research findings, and methods of diagnosis and control. The book contains chapters on animal housing for pathogen exclusion or containment, pathogen surveillance, and pathogens of rats, mice, gerbils, hamsters, guinea pigs, rabbits, ferrets, cats, dogs, swine, and nonhuman primates. It describes a historical perspective on changes in the general awareness of laboratory animal pathogens and an overview of the important distinction between infection and disease.

\section{Amended Law Bans Interstate Commerce of Certain Wild Cats}

On 19 December 2003, President Bush signed into law the 'Captive Wildlife Safety Act' to ban the interstate commerce of certain species of wild cats bound for the exotic pet trade $^{2}$. The Act, which amends the Lacey Act Amendments of 1981 to further the conservation of certain wildlife species, prohibits interstate commerce of any lion, tiger, leopard, cheetah, jaguar, or cougar species, or any hybrid of such a species.

This ban does not apply to importation, exportation, transportation, sale, receipt, acquisition, or purchase of an animal of a prohibited wildlife species, by a person that: "(A) is licensed and inspected by the Animal and Plant Health Inspection Service with respect to that species; (B) is a State college, university, or agency, Statelicensed wildlife rehabilitator, or Statelicensed veterinarian; (C) is an accredited wildlife sanctuary that cares for prohibited wildlife species and-(i) is a corporation that is exempt from taxation under section 501(a) of the Internal Revenue Code 1986 and described in sections 501(c)(3) and 170(b)(1)(A)(vi) of such Code; (ii) does not commercially trade [these wild cat species], including offspring, parts, and byproducts of such animals; (iii) does not propagate animals; and (iv) does not allow direct contact between the public and animals; or (D) has custody of the animal solely for the purpose of expeditiously transporting the animal to a person described in this paragraph with respect to the species ${ }^{2}$."

\section{References}

1. HR 1367. National Veterinary Medical Service Act. 108th Congress, $1^{\text {st }}$ Session.

2. HR 1006. Captive Wildlife Safety Act. 108th Congress, 1st Session.

3. Sewell, D.L. Cumitech 40: Packing and Shipping Diagnostic Specimens and Infectious Substances (ASM Press, Washington, DC, 2003).

4. Baker, D.J. Natural Pathogens of Laboratory Animals: Their Effects on Research (ASM Press, Washington, DC, 2003). 